\title{
Regulate Axon Branching by the Cyclic GMP Pathway via Inhibition of Glycogen Synthase Kinase 3 in Dorsal Root Ganglion Sensory Neurons
}

\author{
Zhen Zhao, ${ }^{1,2}$ Zheng Wang, ${ }^{1}$ Ying Gu, ${ }^{1}$ Robert Feil, ${ }^{3}$ Franz Hofmann, ${ }^{3}$ and Le $\mathrm{Ma}^{1,2}$ \\ ${ }^{1}$ Zilkha Neurogenetic Institute, Department of Cell and Neurobiology, Keck School of Medicine, and ${ }^{2}$ Neuroscience Graduate Program, University of \\ Southern California, Los Angeles, California 90089, and ${ }^{3}$ Institut für Pharmakologie und Toxikologie, Technische Universität, D-80802 Munich, Germany
}

Cyclic GMP has been proposed to regulate axonal development, but the molecular and cellular mechanisms underlying the formation of axon branches are not well understood. Here, we report the use of rodent embryonic sensory neurons from the dorsal root ganglion (DRG) to demonstrate the role of cGMP signaling in axon branching and to identify the downstream molecular pathway mediating this novel regulation. Pharmacologically, a specific cGMP analog promotes DRG axon branching in culture, and this activity can be achieved by activating the endogenous soluble guanylyl cyclase that produces cGMP. At the molecular level, the cGMP-dependent protein kinase 1 (PrkG1) mediates this activity, as DRG neurons isolated from the kinase-deficient mouse fail to respond to cGMP activation to make branches, whereas overexpression of a PrkG1 mutant with a higher-than-normal basal kinase activity is sufficient to induce branching. In addition, cGMP activation in DRG neurons leads to phosphorylation of glycogen synthase kinase 3 (GSK3), a protein that normally suppresses branching. This interaction is direct, because PrkG1 binds GSK3 in heterologous cells and the purified kinase can phosphorylate GSK3 in vitro. More importantly, overexpression of a dominant active form of GSK3 suppresses cGMP-dependent branching in DRG neurons. Thus, our study establishes an intrinsic signaling cascade that links cGMP activation to GSK3 inhibition in controlling axon branching during sensory axon development.

Key words: axon branching; cGMP; PrkG1; GSK3; bifurcation; sensory neuron

\section{Introduction}

The development of neuronal circuits depends on the formation of axonal branches at the right time and the right location (O'Leary and Terashima, 1988). It involves cytoskeleton remodeling controlled by extracellular cues and intrinsic determinants, but the signaling mechanisms underlying such regulation remain poorly understood (Dent et al., 2003).

The pathway involving the cyclic guanosine- $3^{\prime}, 5^{\prime}-$ monophosphate (cGMP) may provide a unique signaling mechanism in regulating axon branching. cGMP is a second messenger involved in a variety of biological regulation (Feil et al., 2005). In the nervous system, it modulates neurotransmitter release, neuronal survival, and possibly synaptic plasticity (Fiscus, 2002; Feil et al., 2003; Kleppisch et al., 2003; Barnstable et al., 2004). During axonal development, cGMP signaling has been implicated in

\footnotetext{
Received Aug. 5, 2008; revised Nov. 26, 2008; accepted Dec. 24, 2008.

This work was supported by a research grant from the Whitehall Foundation. We thank members of the Ma laboratory for helpful discussion, Qiang Wu for in situ analysis, Xi He (Children's Hospital, Boston) for providing the wild-type GSK3 $\beta$ construct, Xiaoping Du (University of Illinois, Chicago) for sending the breeding pair of PrkG1 mice, Virginia Lee (University of Pennsylvania) for providing the neurofilament antibody, and Jonah Chan (University of Southern (alifornia) for sharing the Axiolmager microscope. We are deeply indebted to the continuing support and guidance from Marc Tessier-Lavigne, in whose laboratory this work was conceived.

Correspondence should be addressed to Le Ma, Zilkha Neurogenetic Institute, Keck School of Medicine, University of Southern California, 1510 San Pablo Street, Los Angeles, CA 90089. E-mail: le.ma@usc.edu.

R. Feil's present address: Interfakultäres Institut für Biochemie, Universität Tübingen, 72074 Tübingen, Germany. D0I:10.1523/JNEUROSCI.3770-08.2009

Copyright $\odot 2009$ Society for Neuroscience $\quad$ 0270-6474/09/291350-11\$15.00/0
}

modulating growth cone response to extracellular guidance cues, with high levels of cGMP promoting attraction while low levels promoting repulsion (Song and Poo, 2001). Pharmacological studies in intact animals or slice cultures have shown that manipulation of a number of enzymes that regulate cGMP levels perturbs the growth of both axons and dendrites (Gibbs and Truman, 1998; Cogen and Cohen-Cory, 2000; Polleux et al., 2000; Seidel and Bicker, 2000; Xiong et al., 2007). Furthermore, the key enzymes in cGMP metabolism and signaling are expressed in brain regions, such as cerebellum and hippocampus, which are highly plastic during development (Lein et al., 2007). Finally, the mouse lacking cGMP-dependent protein kinase 1 (PrkG1) has a defect in the central axonal projection of the dorsal root ganglion (DRG) sensory neurons (Schmidt et al., 2002, 2007).

However, many questions remain regarding the precise mechanisms of cGMP signaling in axon branching. Although the notion of its function in axon branching is consistent with its positive role in axon guidance as well as the defect in the PrkG1 knock-out mouse (Schmidt et al., 2007), it is not clear if activation of cGMP signaling is sufficient to promote branch formation. In addition, since the cGMP function is mediated by a number of immediate targets (Hofmann et al., 2000), it needs to be firmly established that PrkG is the key molecular mediator of branching. Furthermore, although many proteins mediate PrkG signaling in other cellular processes (Hofmann et al., 2000), no 
substrate has been defined that is responsible for cGMP function in axonal development, and particularly in branching.

In this report, we address these issues by investigating cGMP signaling in a well established three-dimensional culture system of embryonic DRG neurons (Wang et al., 1999). We find that activation of the CGMP pathway indeed promotes branch formation, thus providing strong evidence to establish its role in branching morphogenesis. We also demonstrate the requirement of PrkG1 and reveal that its kinase activity is both necessary and sufficient for this function. Finally, we provide biochemical and functional evidence to link this novel activity to the regulation of GSK3, a kinase involved in growth factor-dependent axon branching (Kim et al., 2006). Thus, our study establishes an intrinsic signaling cascade that regulates branching by cGMP signaling during axonal development.

\section{Materials and Methods}

Chemicals, animals, and DNA constructs. 8-Br-cGMP and 8-Br-cAMP were obtained from Sigma and KT5823. YC-1, Wortmannin, LY294002, U0126 were obtained from Axxora. All animal works were done according to the protocols approved by the Institutional Animal Care and Use Committees at the University of Southern California following the National Institutes of Health regulations. Rat embryos were collected from pregnant Sprague Dawley females (purchased from Charles River Laboratories) with the plug day designated as embryonic day 0 (E0). PrkG1 mutant embryos in a mixed CD-1/C57B6 background were generated by crossing heterozygous animals with the plug day as E0.5. Genotyping was done by PCR as previously described (Wegener et al., 2002). The mouse PrkG1 $\alpha$ full-length clone was obtained from RIKEN (DB0073L22), and then cloned into the pCAGGS expression vector by PCR with the FLAG sequence incorporated into the primers. The full-length HA-tagged GSK3 $\beta$ (gift from Dr. Xi He, Children's Hospital, Boston, MA) was cloned into the pCAGGS vector by restriction digestions. All single amino acid mutations were generated using QuickChange Mutagenesis kit (Stratagene) and truncation mutants were generated by PCR. For bacterial expression, His-tagged GSK3 $\beta$ was generated by subcloning the full-length HA-tagged GSK3 $\beta$ to $\mathrm{C}$ terminal of the $6 \mathrm{xH}$ His sequence in the pQE30 vector (Qiagen).

In vitro primary DRG neuron culture. All cultures were done in an F12 medium (Invitrogen) with the N3 supplement, $40 \mathrm{~mm}$ glucose, $0.5 \%$ fetal calf serum (FCS) plus NGF $(25 \mathrm{ng} / \mathrm{ml}, 7 \mathrm{~s}$, Sigma). For the in vitro branching assay, DRG neurons from E14 rat embryos were dissociated and cultured at 8000 cells per $20 \mu \mathrm{l}$ of collagen gels (Wang et al., 1999). After one day in culture, they were treated with 8-Br-cGMP and other pharmacological reagents. Cells were fixed after another $24 \mathrm{~h}$ and stained for visualization. For PrkG1 mutant mouse neurons, they were collected and pooled together from E12.5 embryos with the same genotype and then dissociated and cultured as described above.

For expression of various constructs of PrkG1 $\alpha$ or GSK $3 \beta$ in rat E14 DRG neurons, $\sim 1 \times 10^{6}$ dissociated cells were electroporated with 2-3 $\mu \mathrm{g}$ of plasmid DNA using the nucleofection reagent for rat DRG neurons (Amaxa). After electroporation, cells were diluted with $400 \mu \mathrm{l}$ of growth medium, incubated at $37^{\circ} \mathrm{C}$ for $10 \mathrm{~min}$, and then plated together with EGFP-transfected cells (1:1 or 1:2 ratio) at $3-5 \times 10^{4}$ in $20 \mu$ l of collagen gels.

Immunohistochemistry and analysis of axon length and branching points. Cultured neurons were fixed with $4 \%$ paraformaldehyde in PBS, $\mathrm{pH} 7.4$, for $1 \mathrm{~h}$, and permeabilized and blocked with PBS containing $0.1 \%$ Triton X-100 and 1\% Goat Serum. For untransfected culture, neurons were stained with a monoclonal antibody against neurofilament (RMO270, 1:1000, gift from Dr. Virginia Lee, University of Pennsylvania, Philadelphia, PA), an HRP conjugated secondary antibody (Jackson ImmunoResearch, 1:1000), then developed with diaminobenzadine (Sigma). Images were taken on a dissection scope with AxioCamHRc (Zeiss). For TUNEL staining, cells were fixed as above and stained following the manufacturer's protocol (Roche). The transfected cells were stained with mouse anti-FLAG (M2, 1:2000, Sigma) or rabbit anti-HA
(1:500, Santa Cruz), and then Alexa- (Invitrogen) or Cy3- (Jackson ImmunoResearch) conjugated secondary antibodies to detected PrkG1 $\alpha$ or GSK $3 \beta$ expression. Images were taken on an Axiovert 200 inverted microscope with AxioCamMRm (Zeiss).

Images were analyzed using the AxioVision software (Zeiss) or NIH ImageJ for the following parameters: number of neurons with neurites, neuritic length, number of branching points. Only neurons with axons longer than $50 \mu \mathrm{m}$ were counted. Neurites longer than $20 \mu \mathrm{m}$ (about the diameter of a soma) were traced and counted as branches. Each condition was repeated at least twice, and in a single experiment of each condition, $>50$ neurons were analyzed. Statistical significance was determined with independent $t$ test and one way ANOVA. For distribution, the data were presented as mean \pm STD, and for the rest of the analysis, the data were presented as mean \pm SEM.

In situ hybridization. Mouse embryos from different stages were cut on a cryostat (Microm HM560). Sections (16 $\mu \mathrm{m})$ were processed for in situ analysis following a standard procedure using digoxigenin-labeled RNA probes for PrkG1 $\alpha$ (1-267 bp), PrkG1 $\beta$ (1-322bp), and PrkG2 (1062$1740 \mathrm{bp}$ ). Images were obtained on a dissection microscope with AxioCamHMc (Zeiss).

DRG axon tracing with DiI. To label DRG axons inside the spinal cord, E13.5 mouse embryos were fixed and implanted with large DiI crystals or injected with small amount of DiI by iontophoresis as previously described (Ma and Tessier-Lavigne, 2007). The dye was allowed to diffuse at $25^{\circ} \mathrm{C}$ overnight before visualization on an AxioImager microscope with AxioCamMRm (Zeiss).

Analysis of protein phosphorylation by Western blots. Proteins were separated by SDS-PAGE and transferred onto nitrocellulose membranes, which were probed with the following antibodies: rabbit anti-HA (Santa Cruz); rabbit anti-phospho-GSK3 (Ser9), rabbit anti-phospho-Akt (Ser473), rabbit anti-phospho-ERK (Thr202) (Cell Signaling); and mouse anti-tubulin (DM1 $\alpha)$. Alexa680- (Invitrogen) and IRDye800labeled secondary antibodies were used for detection on an infrared imaging system (Odyssey, LI-COR). Experiments were done multiple times, and the quantification was done for the blots represented in the figures.

GSK3 phosphorylation assay in neurons or COS cells. Neuronal cell lysates were prepared in ice-cold RIPA buffer with protease inhibitors and phosphatase inhibitors from E14 rat DRG neurons $\left(4 \times 10^{5}\right.$ cells/ well) that were cultured overnight, starved for $3 \mathrm{~h}$ without NGF and stimulated for different times with $50 \mu \mathrm{M} 8$-Br-cGMP or $50 \mathrm{ng} / \mathrm{ml} \mathrm{NGF}$. COS cells transfected with different combinations of GSK $3 \beta$ and PrkG1 $\alpha$ were grown in serum-free medium for one day before lysed in the above buffer. Proteins from the lysates were then subjected to Western blotting described above.

Coimmunoprecipitation. COS cells were cultured in 6-well plates, and transfected by FuGene 6 (Roche) with different combinations of HAtagged GSK $3 \beta$, Flag-tagged PrkG1 $\alpha$, Flag-tagged PrkG1 $\alpha$-S64A, and EGFP. Two days after transfection, cells from each well were collected by scraping, pelleted by centrifugation, and then lysed in $100 \mu \mathrm{l}$ of buffer containing $50 \mathrm{~mm}$ Tris- $\mathrm{HCl}$, pH 7.5, $50 \mathrm{~mm} \mathrm{NaCl}, 1 \mathrm{~mm}$ EDTA, 1.25\% Triton X-100 and a protease inhibitor mixture (Roche). Each $50 \mu \mathrm{l}$ of lysate was diluted to a final volume of $1 \mathrm{ml}$ with PBS, incubated overnight with anti-HA (Santa Cruz) or anti-Flag antibody (Sigma) at $4^{\circ} \mathrm{C}$, and then precipitated with precleaned protein A Sepharose beads (GE Healthcare Life Sciences). The beads were washed three times with PBS before elution with $50 \mu \mathrm{l}$ of gel loading buffer for Western blot.

In vitro phosphorylation assays. In vitro phosphorylation of GSK3 $\beta$ using COS cell lysates or the purified kinase was performed in a total volume of $40 \mu \mathrm{l}$ of kinase assay buffer containing $20 \mathrm{~mm}$ Tris- $\mathrm{HCl}, \mathrm{pH}$ 7.5, $20 \mathrm{~mm}$ magnesium acetate, $100 \mu \mathrm{M}$ ATP, $2 \mathrm{~mm}$ dithiothreitol, with or without $20 \mu \mathrm{M} 8-\mathrm{Br}-\mathrm{cGMP}$. The reaction was incubated at $30^{\circ} \mathrm{C}$ for different time points, and stopped by heating at $95^{\circ} \mathrm{C}$ for $5 \mathrm{~min}$. Protein samples were separated by SDS-PAGE and blotted as described above. His-tagged GSK $3 \beta$ was expressed in E. coli (strain M15) and purified from the soluble lysate using a Hi-Trap Ni column (Pharmacia) under the native condition. Purified GSK3 $\beta$ proteins were dialyzed against a buffer containing $20 \mathrm{~mm}$ Tris- $\mathrm{HCl}, \mathrm{pH} 7.5$, and $20 \mathrm{~mm}$ magnesium acetate, and $200 \mathrm{ng}$ was used in each kinase assay. The PrkG1 $\alpha$-S64A lysate 
was prepared from transfected COS cells (100 $\mu l$ per $10 \mathrm{~cm}$ culture dish) and $5 \mu$ lof the lysate was used in the assay. Purified PrkG1 $\alpha$ protein from bovine lung was purchased from Calbiochem, and $\sim 400 \mathrm{ng}$ (1500) units of proteins were used per reaction.

\section{Results}

cGMP activation in cultured DRG neurons leads to the formation of multiple axonal branches

To identify signaling mechanisms involved in axon branching, we tested a number of chemical activators in an in vitro culture of dissociated E14 rat DRG neurons. As described previously (Wang et al., 1999), DRG neurons at this age normally have simple morphology when cultured in collagen gels, with a single axon extending out from the cell body (Fig. $1 A-C$ ). As shown by the distribution, $>40 \%$ of neurons had no branch, about half made one, and $<10 \%$ generated more than two branches (Fig. $1 M$ ). Interestingly however, when treated with 8-bromoguanosine- $3^{\prime}, 5^{\prime}$ cyclic monophosphate (8-Br-cGMP), a commonly used membrane-permeable analog of cGMP (Schwarzschild and Zigmond, 1991) for just $1 \mathrm{~d}$, these neurons made more than one branches from the single axon, with some having four or five per axon (Fig. $1 D-F$ ). This effect can be seen at the 8-Br-cGMP concentration as low as $2 \mu \mathrm{M}$, and with the increasing analog concentration, the distribution shifted toward the right, indicating an increase in neurons with more branches (Fig. $1 \mathrm{M}$ ). At the highest concentration $(200 \mu \mathrm{M})$ tested, $>50 \%$ cells had more than two branches, while $<10 \%$ had no branches (Fig. $1 M$ ). On average, the number of branching points per cell at $200 \mu \mathrm{M}$ 8-Br-cGMP reached 2.8 -fold of that from the control neurons, which contain less than one branch per cell (Fig. $1 P$ ).

This cGMP effect on DRG axon branching is specific, because 8-bromoadenosine-3', $5^{\prime}$-cyclic monophosphate (8-Br-cAMP), an equivalent analog to activate the cAMP pathway, did not elicit the same effect (Fig. $1 G-I$ ). Neither the distribution nor the average number of branching points changed significantly in the 8-Br-cAMP-treated culture compared with the untreated one (Fig. $1 N, P$ ). Furthermore, YC-1, a small molecule that activates the soluble guanylyl cyclase (sGC) to produce cGMP (Galle et al., 1999), induced branch formation in a dose dependent manner, reaching a similar level as in the 8-Br-cGMP-treated culture (Fig. $1 J-L, O, P$ ). Conversely, Zaprinast, an inhibitor that prevents cGMP degradation by phosphodiesterase-5 (Dundore et al., 1993), also induced branching (data not shown).

We further examined several parameters to determine if the in vitro effect reflects the role of cGMP signaling in axon growth or
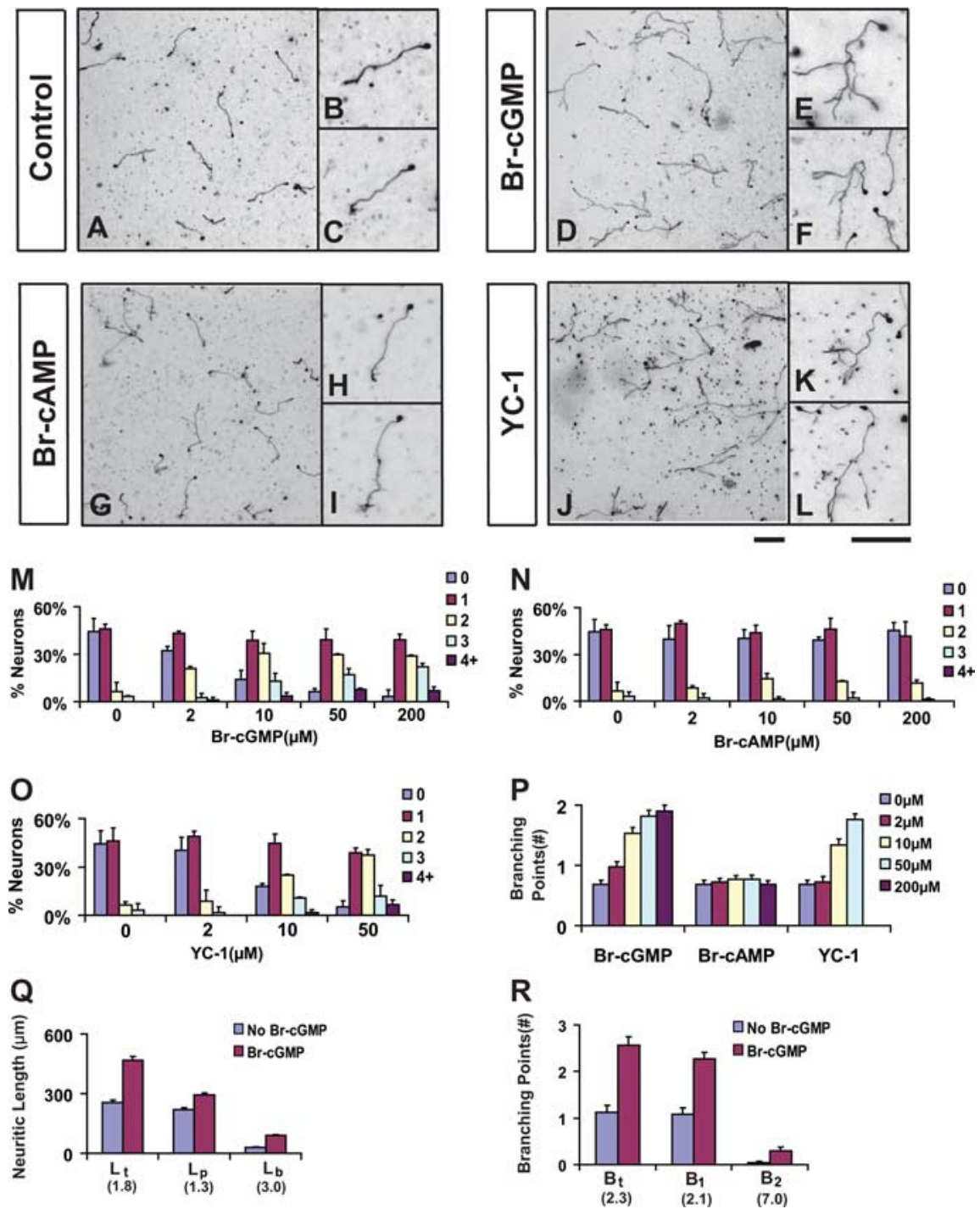

Figure 1. Activation of CGMP promotes axon branching in cultured DRG neurons. $A-L, D R G$ neurons from $E 14$ rat embryos were dissociated and cultured in collagen gels in the presence of NGF for $24 \mathrm{~h}$ and then treated with buffer $(\boldsymbol{A}-\boldsymbol{C}), 8-\mathrm{Br}-\mathrm{CGMP}(50 \mu \mathrm{M}$, $\boldsymbol{D}-\boldsymbol{F}), 8-B r-c A M P(50 \mu \mathrm{m}, \boldsymbol{G}-\boldsymbol{I})$, or YC-1 $(20 \mu \mathrm{m}, \boldsymbol{J}-\boldsymbol{L})$. After cultured for another day, they were fixed and stained with antibody against neurofilament. Regions of the cultures are shown at low magnification in $\boldsymbol{A}, \boldsymbol{D}, \mathbf{G}$, and $\boldsymbol{J}$, while individual cell morphologies are shown at high magnification in $\boldsymbol{B}, \boldsymbol{C}, \boldsymbol{E}, \boldsymbol{F}, \boldsymbol{H}, \boldsymbol{I}, \boldsymbol{K}$, and $\boldsymbol{L}$. Neurons treated with 8-Br-cGMP or YC-1 but not 8-Br-cAMP showed a significant increase in branches formed from a single axon extending from the cell body. Scale bars, $100 \mu \mathrm{m}$. M-0, Comparison of axon branching by the distribution of neurons with different number of branches in the above cultures treated with different concentrations of each chemical. $\boldsymbol{P}$, Comparison of the average number of branching points measured from neurons cultured under different chemical concentrations. $\mathbf{Q}, \boldsymbol{R}$, Comparison of the length of total neurites $\left(L_{t}\right)$, primary axons $\left(L_{p}\right)$ and total branches $\left(L_{b}\right)$ and the number of branching points of total $\left(B_{t}=B_{1}\right.$ and $\left.B_{2}\right)$, primary $\left(B_{1}\right)$ and secondary $\left(B_{2}\right)$ branches in separate experiments. The numbers in parentheses indicate the fold change between neurons treated with and without $50 \mu \mathrm{m} 8-\mathrm{Br}-\mathrm{cGMP}$.

branching. First, neurons from the control cultures had a total length $\left(\mathrm{L}_{\mathrm{t}}\right)$ of $254 \pm 14 \mu \mathrm{m}$, but neurons treated with 8-Br-cGMP had a nearly twofold increase, reaching $467 \pm 20 \mu \mathrm{m}$ per cell (Fig. $1 Q)$. The $80 \%$ increase in $\mathrm{L}_{\mathrm{t}}$ is not contributed solely by the elongation of primary axons, as its length $\left(\mathrm{L}_{\mathrm{p}}\right)$ increased only modestly by $30 \%$ (Fig. $1 Q$ ). Instead, it reflects the increased length of primary and secondary branches, as the total branch length $\left(\mathrm{L}_{\mathrm{b}}\right)$ per cell had a twofold increase (Fig. 1Q). In addition, this increase appears to be driven by the increased branching numbers in cGMP-treated neurons, as we found a 1 -fold increase for primary branches $\left(B_{1}\right)$, a 6-fold increase for secondary branches $\left(B_{2}\right)$, and an overall 1.3-fold increase in all branches $\left(B_{t}\right)$ (Fig. $1 R$ ). Furthermore, we found no linear correlation between 


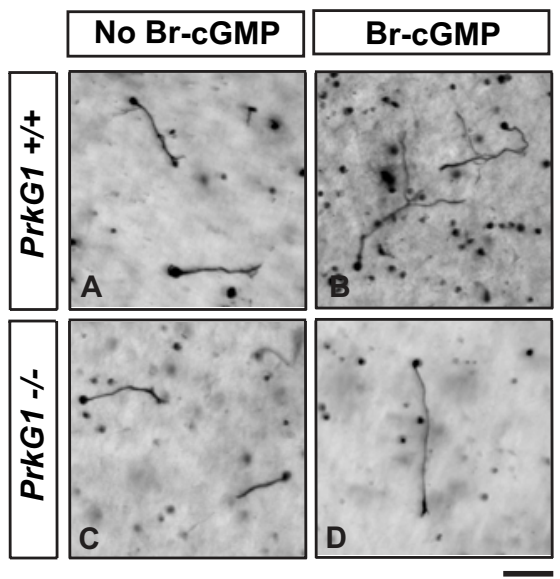

E
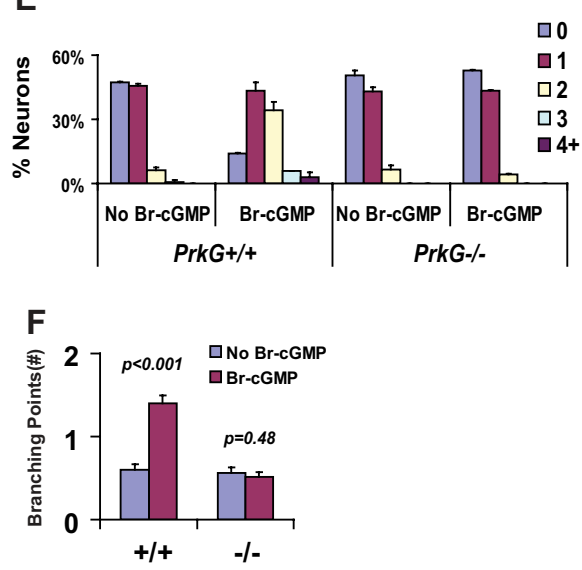
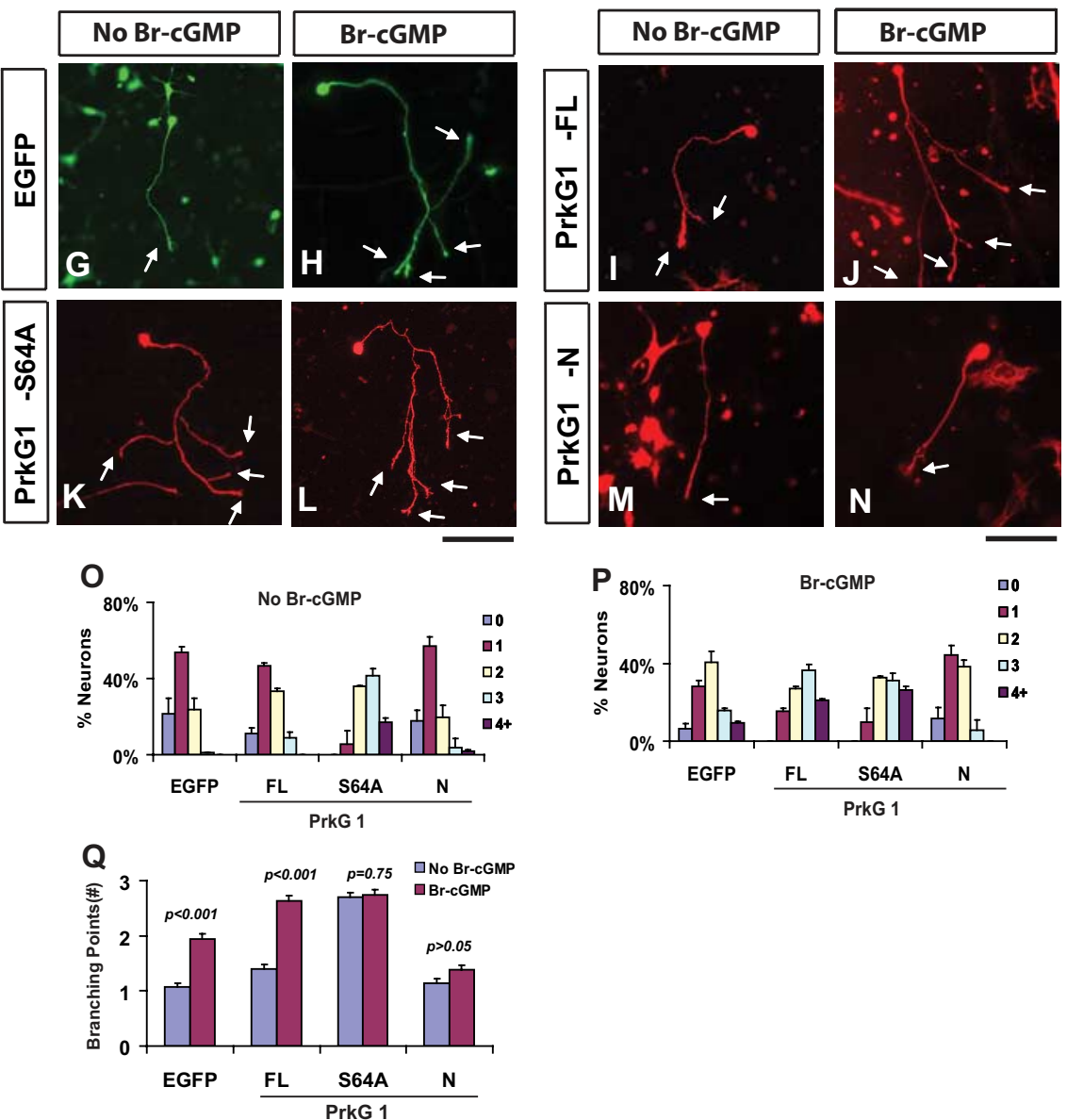

Figure 2. PrkG1 is both necessary and sufficient for DRG axon branching in culture. $A-D, D R G$ neurons from PrkG1 mutant mice do not support axon branching after cGMP activation. E12.5 mouse DRG neurons from wild-type $(+/+, \boldsymbol{A}, \boldsymbol{B})$ or PrkG1 mutant $(-/-, \boldsymbol{C}, \boldsymbol{D})$ littermates were cultured for $2 \mathrm{~d}$ in collagen gels and treated with $(\boldsymbol{B}, \boldsymbol{D})$ or without $(\boldsymbol{A}, \boldsymbol{C}) 50$ $\mu \mathrm{M} 8$-Br-cGMP on the second day. They are visualized by antibody staining for neurofilament. Note that wild-type neurons $(\boldsymbol{B})$, but not the PrkG1 ${ }^{-/-}$cells $(\boldsymbol{D})$, generated more branches in the presence of Br-cGMP. Scale bar, $100 \mu \mathrm{m} . \boldsymbol{E}, \boldsymbol{F}$, The difference in the above culture is shown by the change in the distribution of cells with different branch numbers $(\boldsymbol{E})$ and the average number of branching points $(\boldsymbol{F})$. $\mathbf{G}-\boldsymbol{M}$, Overexpression of PrkG1 $\alpha$ mutants modulates axon branching in DRG neurons. Dissociated rat E14 DRG neurons transfected with either EGFP $(\boldsymbol{G}, \boldsymbol{H})$, the full length (-FL, $\boldsymbol{I}, \boldsymbol{J})$, the $\mathbf{S 6 4 A}$ mutant $(-S 64 A)(\boldsymbol{K}, \boldsymbol{L})$ or the N-terminal fragment $(\mathrm{N})(\boldsymbol{M}, \boldsymbol{N})$ of PrkG1 $\alpha$ were cultured for 2 d in collagen gels and treated with $(\boldsymbol{H}, \boldsymbol{J}, \boldsymbol{L}, \boldsymbol{N})$ or without $(\boldsymbol{G}, \boldsymbol{I}, \boldsymbol{K}, \boldsymbol{M}) 50 \mu \mathrm{M}$ 8-Br-cGMP. They are visualized based on the EGFP fluorescence $(\mathbf{G}, \boldsymbol{H})$ or antibody staining against the FLAG tag fused to the PrkG1 $\alpha$ proteins $(\boldsymbol{I}-\boldsymbol{N})$. The S64A mutant induced the formation of multiple branches (arrows) in the absence of 8-Br-cGMP $(\boldsymbol{K})$, while the N-terminal fragment blocked 8-Br-cGMP-induced branching $(\boldsymbol{M})$. Arrows point to the end of axonal branches. Scale bars, $100 \boldsymbol{\mu m}$. $\mathbf{0}-\mathbf{Q}, \mathrm{The}$ difference in the above culture is shown by the change in the distribution of cells with different branch numbers $(\mathbf{Q}, \mathbf{P})$ and the average number of branching points $(\mathbf{Q})$. Statistical differences are shown by the $p$ values.

$\mathrm{L}_{\mathrm{p}}$ and $\mathrm{B}_{\mathrm{t}}$ for all the neurons analyzed (supplemental Fig. 1, available at www.jneurosci.org as supplemental material), indicating cGMP-stimulated branch formation is independent of the growth of primary axons. Thus, the effect of cGMP on axon branching is mediated mainly by promoting branch formation instead of accelerated axon growth.

Finally, we examined the possible role of cGMP signaling in regulating neuronal survival and axongenesis as previously suggested (Thippeswamy and Morris, 1997; Seidel and Bicker, 2000; Fiscus, 2002). As shown by TUNEL staining, the cell death did not change significantly in the cultures treated with 8-Br-cGMP compared with the untreated control (supplemental Fig. $2 \mathrm{~A}$, available at www.jneurosci.org as supplemental material). In addition, these neurons usually made only one axon per cell body in collagen gels, and this number did not change after cGMP stimulation, indicating that the pathway does not promote axonogenesis (data not shown). This conclusion is further supported by our study of BAX null DRG neurons (Lentz et al., 1999), which survived in the absence of NGF but did not make more axons in the presence of 8-Br-cGMP (supplemental Fig. 2B, available at www.jneurosci.org as supplemental material).
Together, these analyses have revealed that the cGMP pathway can provide a specific intracellular signaling mechanism that promotes branch formation in culture.

\section{Activation of PrkG1 is both necessary and sufficient for DRG axon branching in culture}

Since a number of immediate downstream targets are known for mediating cGMP signaling in different cellular processes, we next wanted to identify the mediator for this novel branching activity. We focused our study on PrkG1, because it is expressed in the DRG (see Fig. 3F-I) (Schmidt et al., 2002). In addition, KT5823, a specific inhibitor that interferes with the ATP binding site of the catalytic domain of PrkG (Hidaka and Kobayashi, 1992), blocked the branching effect in culture (supplemental Fig. 3, available at www.jneurosci.org as supplemental material). To test its requirement in the in vitro assay, we isolated DRG neurons from E12.5 PrkG1 null embryos (Wegener et al., 2002) and examined their response to 8-Br-cGMP in culture. These neurons, equivalent to E14 rat DRG cells, normally had simple morphology but made more branches in response to 8-Br-cGMP (Fig. $2 A, B$ ). However, despite growing normally (Fig. $2 C$ ) with no defect in survival 
A

\section{E13.5}

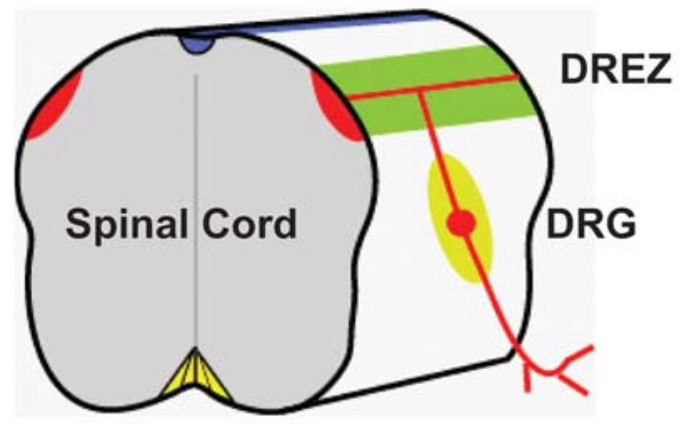

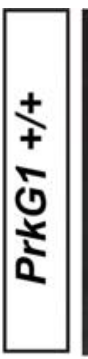
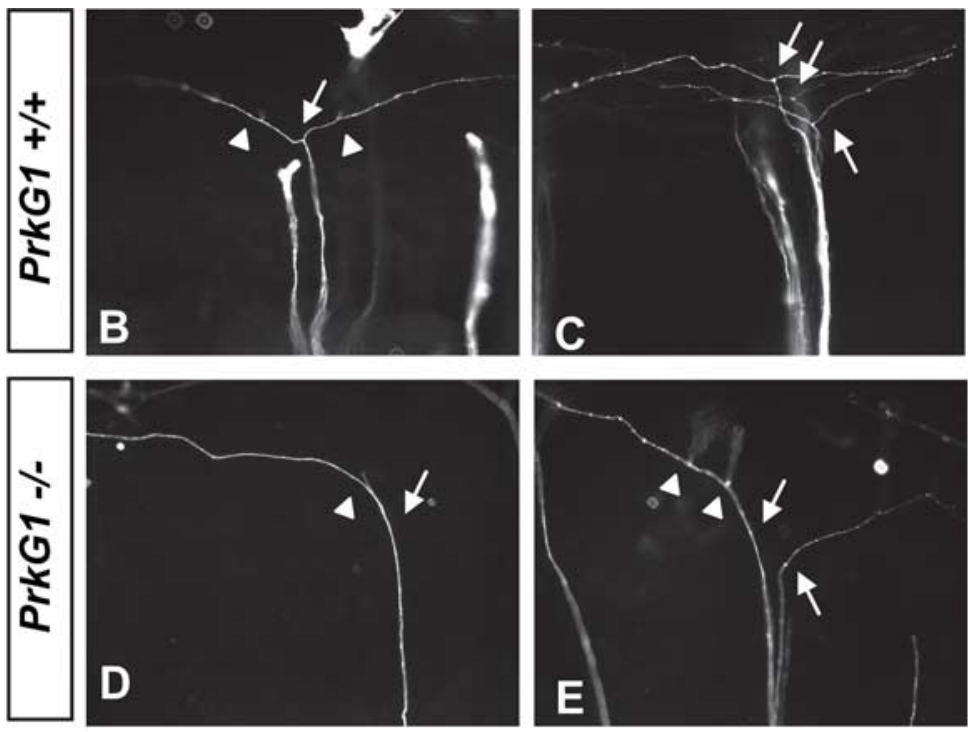
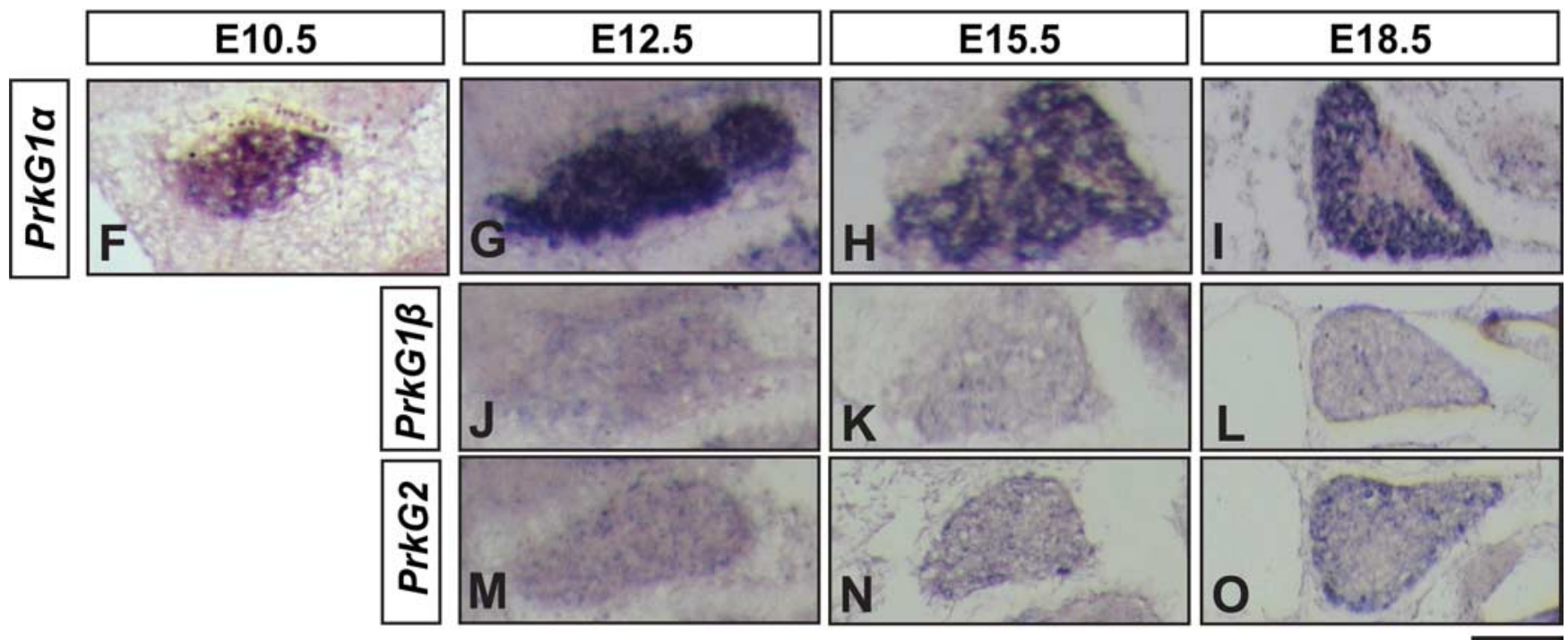

Figure 3. Requirement of PrkG1 in DRG axon bifurcation during early embryonic development. $\boldsymbol{A}, \mathrm{A}$ diagram showing the projections of sensory neurons in the E13.5 spinal cord. $\boldsymbol{B}-\boldsymbol{E}$, Visualization of Dil-labeled DRG axon projections at the single-cell resolution. Images were taken from the lateral side of E13.5 spinal cords in an open book preparation. Normally in the wild-type spinal cord, sensory axons bifurcate (arrows) at the DREZ, resulting two daughter branches that extend in opposite directions along the rostrocaudal axis (B, $\boldsymbol{C}$. However, in the PrkG1 ${ }^{-/}$mutant spinal cords $(\boldsymbol{D}, \boldsymbol{E})$, one of the branches is missing, while the other appears to grow normally but turn to either rostral or caudal direction (arrows point to the turning point). Note that the collaterals (arrowheads) are still formed from the remaining axons. Scale bar, $500 \mu \mathrm{m}$. $\boldsymbol{F}-\mathbf{0}$, Expression of three different PrkG isoforms is analyzed in the DRG from E10.5 $(\boldsymbol{F}), \mathrm{E} 12.5(\mathbf{G}, \mathbf{J}, \boldsymbol{M}), \mathrm{E} 15.5(\boldsymbol{H}, \boldsymbol{K}, \boldsymbol{N})$, or E18.5 $(\boldsymbol{I}, \mathbf{L}, \mathbf{0})$ mouse embryos by RNA in situ hybridization using digoxigenin-labeled RNA probes for PrkG1 $\alpha(\boldsymbol{F}-\boldsymbol{I})$, PrkG1 $\beta(\boldsymbol{J}-\mathbf{L})$, and PrkG2 $(\boldsymbol{M}-\mathbf{0})$. Scale bar, $100 \mu \mathrm{m}$.

(data not shown), they failed to make more branches when treated with 8-Br-cGMP (Fig. 2D), as compared with wild-type neurons (Fig. 2E,F). Thus, PrkG1 is indeed required for cGMPstimulated branching in culture.

To further characterize the function of PrkG1, we asked if perturbation of its activity at the molecular level could modulate branching. We generated several mouse PrkG1 $\alpha$ mutants and expressed them in E14 rat DRG neurons by electroporation. We first tested the full-length wild-type PrkG1 $\alpha$ and found only a modest increase in basal branching (by 20\%) as well as in cGMPstimulated branching (by 20\%), as compared with neurons expressing EGFP that were cultured together (Fig. $2 G-J, O-Q$ ). We then tested an S64A mutant, which has twice the basal kinase activity of the wild type and 10-fold higher affinity for cGMP
(Busch et al., 2002). Strikingly, neurons expressing this mutant displayed excessive branches even in the absence of 8-Br-cGMP (Fig. $2 K-L, O-Q$ ). The number of branching points increased nearly 1.5 -fold, indicating that it could promote branching with the endogenous cGMP level (Fig. $2 \mathrm{~K}, \mathrm{O}-\mathrm{Q}$ ). Not surprisingly, 8 -Br-cGMP did not further increase the branching number (Fig. $2 L$ ), suggesting that the kinase was already fully activated or the downstream branching program was limiting. Finally, we overexpressed the $\mathrm{N}$-terminal fragment containing the regulatory domain of PrkG1 $\alpha$, which was reported to be dominant inhibitory (Browning et al., 2001). This protein had little effect on basal axon growth and branching, but blocked branching in neurons treated with 8-Br-cGMP (Fig. $2 M-N, O-Q$ ). Thus, these results 
A

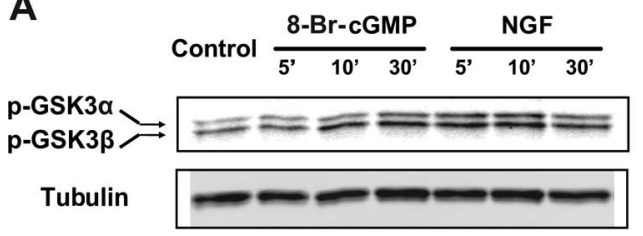

B

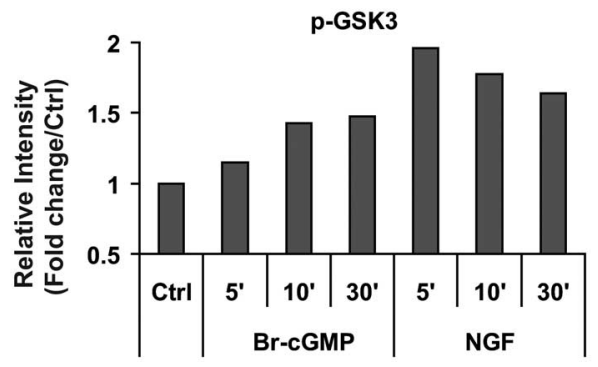

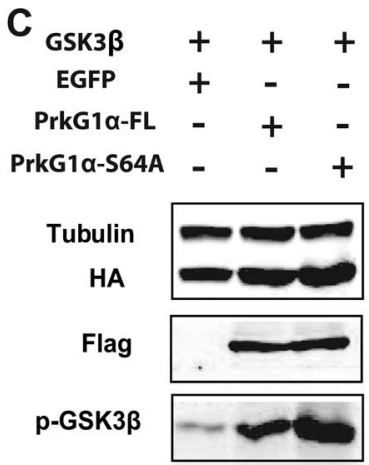

D

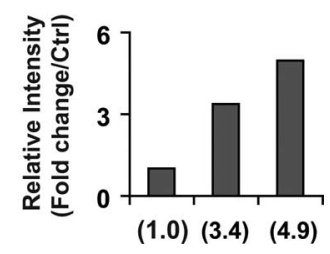

Figure 4. CGMP activation leads to phosphorylation of GSK3 $\sin$ DRG neurons and $\operatorname{COS}$ cells. A, Western blot of phospho-GSK3 $\alpha$ (Ser21) and phospho-GSK3 $\beta$ (Ser9) in extracts from dissociated E14 rat DRG neurons cultured for $24 \mathrm{~h}$. These cells were starved for $3 \mathrm{~h}$ by removing NGF and then treated with $8-B r-\mathrm{CGMP}(50 \mu \mathrm{M})$ or NGF $(50 \mathrm{ng} / \mathrm{ml})$ for the time periods indicated. Tubulin was blotted as a loading control. $\boldsymbol{B}$, The relative level of phosphorylation on the above Western blot $(\boldsymbol{A})$ was calculated based on the intensity of each band, normalized to the expression of tubulin on the same membrane, and compared with the control sample. Note the increase in phosphorylation in extracts treated with 8-Br-CGMP or NGF. C, HA-tagged GSK3 $\beta$ was expressed in COS cells along with EGFP, the full length (FT) or the S64A mutant of PrkG1 $\alpha$. Its phosphorylation was detected by a GSK3 phosphoantibody, while its expression was probed by $\mathrm{HA}$ antibody. PrkG1 $\alpha$ expression was revealed by antibodies against the FLAG tag fused to the protein. Tubulin staining was used as a loading control. D, Quantification of the GSK3 $\beta$ phosphorylation level from the above Western blot $(\boldsymbol{C})$ and the band intensity is normalized sequentially to that from blots for HA for GSK3 $\beta$ and FLAG for PrkG1. The number in the parentheses indicates the fold change compared with the control sample expressing GSK3 $\beta$ and EGFP.

demonstrate that PrkG1 is the key mediator for the cGMP pathway in axon branching.

\section{Developmental requirement of cGMP signaling in DRG axon bifurcation in mice}

To understand the physiological significance of the branching activity we found in culture, we next examined the development of DRG axons in the PrkG1 knock-out mice, in which DRG central afferents have been shown to misproject at the dorsal root entry zone (DREZ) (Schmidt et al., 2002). Consistently, mutant DRG afferents labeled by DiI were often found more in one direction than the other in the DREZ, without a clear rostral or caudal preference (supplemental Fig. 4, available at www.jneurosci.org as supplemental material). To examine individual axons, we used DiI iontophoresis to label DRG axon in the E13.5 spinal cord (Fig. 3A-E). As described previously (Ozaki and Snider, 1997; Ma and Tessier-Lavigne, 2007), nearly all axons formed symmetric T- or Y-shaped bifurcation fork in wild-type or heterozygous littermates, and very rarely did they turn to the longitudinal tract without bifurcation (1.4\% for wild type and 5.5\% for the heterozygous) (Fig. $3 B, C$; supplemental Table 1, available at www.jneurosci.org as supplemental material). However, the majority of DiI-labeled axons (98.6\%) in the mutants did not have two branches and lost either the rostral or the caudal branch in a random manner. The remaining branch turned correctly into the longitudinal track and some already sprouted nascent collaterals, suggesting that the defect is not due to a delay in bifurcation (Fig. $1 D-F$ ). This defect is consistent with the recent report by Schmidt et al. (2007), and correlates well with the expression of PrkG1 $\alpha$ but not the other isoforms during early embryonic development (Fig. $3 F-O$ ). Like those re- ported by the immunohistochemical studies (Qian et al., 1996; Schmidt et al. 2002), PrkG1 $\alpha$ transcript appears at E10.5 (Fig. $1 F$ ) when the pioneer axons reach the spinal cord and begin to bifurcate, peaks at E12.5, and becomes more restricted between E15.5 and E18.5 (Fig. $3 G-I$ ). Thus, these in vivo analyses indicate that cGMP signaling indeed plays a role in DRG axon bifurcation, which is consistent with its activity in promoting branching in culture.

\section{cGMP activation leads to phosphorylation of GSK3 in DRG neurons and $\mathrm{COS}$ cells}

To understand how PrkG1 activation by cGMP controls branching, we attempted to identify the downstream pathways that mediate this novel activity in axonal development. Since our DRG neurons were cultured in the presence of NGF, a possible mechanism for cGMP signaling would be targeting a common downstream pathway involved in branching. Therefore, we examined several targets downstream of NGF signaling, with a focus on GSK $3 \alpha$ and GSK $3 \beta$, two proteins that have been shown to negatively regulate axon growth and branching but can be inhibited by growth factor signaling in DRG neurons (Kim et al., 2006).

We first examined their phosphorylation in cultured DRG neurons by Western blot using a phosphospecific antibody that recognized phosphoserine at position 21 in GSK3 $\alpha$ and position 9 in GSK3 $\beta$ (Fig. $4 A$ ). Within 5 min of 8 -Br-cGMP treatment, the phosphorylation level of both isoforms started to increase, and at $30 \mathrm{~min}$, reached at $\sim 1.5$-fold of the basal level (Fig. 4B). As a comparison, their phosphorylation in response to NGF reached nearly twofold of the basal level within $5 \mathrm{~min}$, similar to what was reported recently (Zhou et al., 2004). In addition, this cGMP-stimulated phosphorylation is dependent on PrkG1, as it was no longer observed in PrkG1 null neurons, which still retained NGF-dependent phosphorylation (supplemental Fig. 5, available at www.jneurosci.org as supplemental material).

We also examined other known downstream molecules involved in NGF signaling, including Akt, the kinase that is activated by phosphatidylinositol 3-kinase (PI3-K) and phosphorylates GSK3, and ERK, the kinase that mediates a separate Raf signaling pathway (see Fig. 7A) (Markus et al., 2002; Zhou et al., 2004; Zhong et al., 2007). Neither protein showed any significant change in phosphorylation in DRG neurons in response to 8-BrcGMP, although they both respond to NGF stimulation (supplemental Fig. 6, available at www.jneurosci.org as supplemental material). Thus, cGMP activation specifically phosphorylates GSK3 in DRG neurons.

To further verify this connection, we analyzed GSK3 phosphorylation by Western blots in COS cells expressing both PrkG1 $\alpha$ and GSK3 $\beta$ (Fig. 4C). In the presence of the full-length PrkG1 $\alpha$ or the S64A mutant, GSK3 $\beta$ phosphorylation increased to 3.4-fold or 4.9-fold, respectively, over the control with EGFP (Fig. 4D). As a comparison, phosphorylation of the endogenous 
Akt did not change significantly (data not shown). Thus, these studies reveal that GSK3 is a potential downstream target for PrkG1 and suggest a mechanism in which cGMP signaling leads to GSK3 phosphorylation and thereby relieves its inhibition of branching in DRG neurons.

\section{PrkG1 $\alpha$ binds and phosphorylates GSK3 directly}

The sequence surrounding the phosphorylation site in both GSK $3 \alpha$ and GSK $3 \beta$ is highly conserved among different species, and the four adjacent residues share high similarity with the consensus sequence (-Arg-Arg-X-Ser/ThrX-) for known PrkG substrates (Fig. 5A). To test if GSK3 could be a direct substrate of PrkG1 $\alpha$, we first determined if GSK3 $\beta$ could physically associate with PrkG1 $\alpha$ in COS cells by immunoprecipitation (Fig. 5B). When the full-length wild type or the S64A mutant of PrkG1 $\alpha$ was coexpressed with HA-tagged GSK3 $\beta$ in COS cells, either PrkGl $\alpha$ protein could be precipitated by the HA-specific antibody. As a control, neither protein came down when they were coexpressed with EGFP, confirming the specificity of the association. In a reciprocal experiment using a FLAG antibody, GSK3 $\beta$ could be coprecipitated with both FLAG tagged PrkG1 $\alpha$ proteins, but not EGFP. Consistently, the S64A mutant had stronger binding than the wild type in both cases.

Next, we asked if GSK $3 \beta$ can be phosphorylated in vitro by COS cell extracts containing overexpressed PrkG1 $\alpha$. We purified the native recombinant GSK3 $\beta$ proteins from bacteria and incubated them with the COS cell lysates containing the S64A mutant of PrkG1 $\alpha$. Phosphorylation of GSK $3 \beta$ revealed by the phosphospecific antibody on Western blots (Fig. 5C) increased by $80 \%$ after $5 \mathrm{~min}$ incubation, peaked at 15 min with 2.6-fold of the basal level, and plateaued between 30 and 60 min (Fig. 5D).

Finally, we tested if GSK $3 \beta$ could be phosphorylated directly by purified PrkG1 $\alpha$ proteins. When the recombinant GSK $3 \beta$ protein was incubated with the kinase purified from the bovine lung tissues at $30^{\circ} \mathrm{C}$ for $30 \mathrm{~min}$ (Fig. $5 E$ ), the phosphorylation signal was increased dramatically by $\sim 3$-fold over the basal condition without the kinase. Moreover, stimulation of the kinase by including 8 -Br-cGMP induced an additional 1.8-fold increase in phosphorylation (Fig. 5F), indicating that PrkG1 phosphorylates GSK3 $\beta$ in a cGMP-dependent manner.

Together, these studies in heterologous cells and with purified proteins suggest that GSK $3 \beta$ is a direct target for cGMP signaling via PrkG1 $\alpha$ phosphorylation.
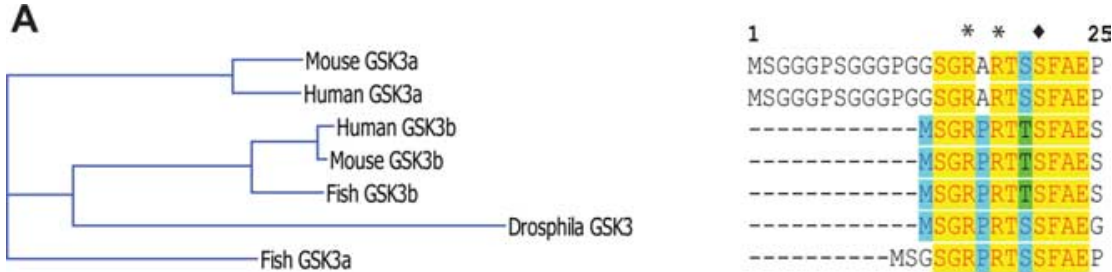

B

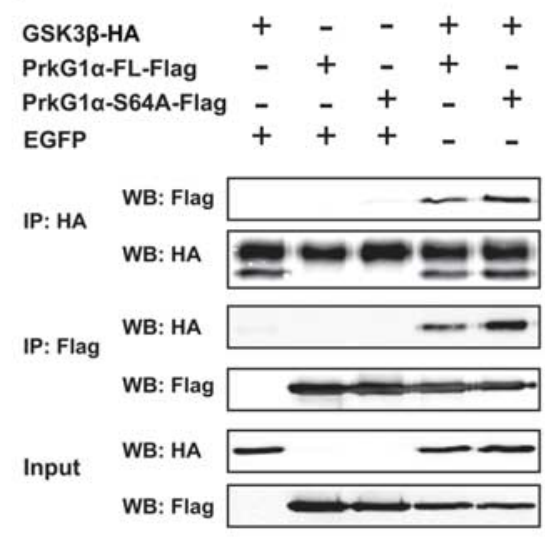

E

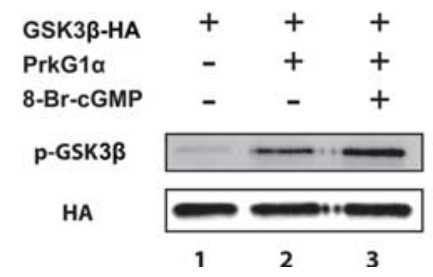

C

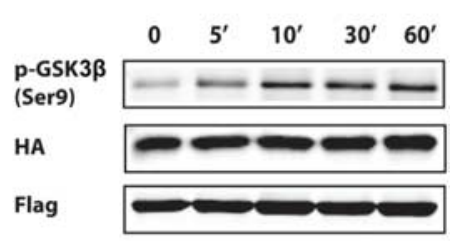

D

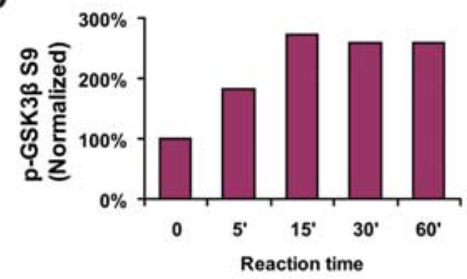

$\mathbf{F}$

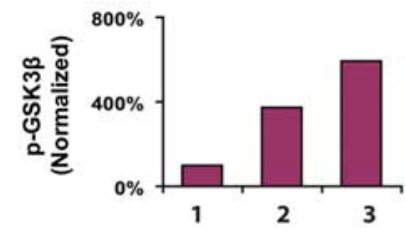

Figure 5. Biochemical interaction of GSK3 $\beta$ with PrkG1 in COS cells and in vitro. $A$, Comparison of the sequences surrounding the N-terminal phosphorylation site in GSK3 $\alpha$ and GSK3 $\beta$ from different species. $\boldsymbol{B}$, Coimmunoprecipitation of HA-tagged GSK3 $\beta$ and Flag-tagged PrkG1 $\alpha$-FL or PrkG1 $\alpha$-S64A. COS-7 cells were transfected with a combination of constructs for GSK3 $\beta$, PrkG1 $\alpha$ FL, PrkG1 $\alpha$-S64A, and EGFP as indicated in the label above the blot. Cell lysates were immunoprecipitated (IP) with anti-HA or anti-Flag antibodies, and probed with antibodies against Flag or HA on Western blots (WB) as indicated on the left side of the top four blots. Coimmunoprecipitation of GSK3 $\beta$ and PrkG1 $\alpha$ or PrkG1 $\alpha$-S64A is shown on the fourth and fifth lane. The cell lysates used for immunoprecipitation were also blotted and probed as input controls (bottom 2 blots). C, D, In vitro phosphorylation of purified GSK3 $\beta$ by COS cell extracts containing PrkG1 $\alpha$-S64A. Cell extracts were prepared from COS-7 cells transfected with a PrkG1 $\alpha$-S64A expression construct and then mixed with recombinant GSK3 $\beta$ proteins ( $200 \mathrm{ng}$ ) purified from bacteria in the kinase assay buffer at $30^{\circ} \mathrm{C}$ for various time points. Phosphorylation of GSK3 $\beta$ at serine- 9 was detected by Western blot using the anti-phospho-GSK3 antibody, and the amount of GSK3 $\beta$ and PrkG1 $\alpha$-S64A was probed with antibodies against HA and Flag, respectively $(\boldsymbol{C})$. The level of phosphorylation was calculated from the band intensity that was normalized to that of $0 \mathrm{~min}(\boldsymbol{D}) . \boldsymbol{E}$, F, GSK3 $\beta$ can be directly phosphorylated by PrkG1 $\alpha$ in vitro. Purified bovine PrkG1 $\alpha$ proteins ( $400 \mathrm{ng}$ ) and GSK3 $\beta$ proteins (200 $\mathrm{ng}$ ) were incubated in the kinase assay buffer with or without $20 \mu \mathrm{m} 8-\mathrm{Br}-\mathrm{cGMP}$ at $30^{\circ} \mathrm{C}$ for $30 \mathrm{~min}$. GSK3 $\beta$ phosphorylation at serine- 9 was analyzed using the specific antibody on the Western blot $(\boldsymbol{E})$. The relative level of phosphorylation was calculated from the band intensity $(\boldsymbol{F})$ normalized to the amount of GSK3 $\beta$ in the reaction that was determined by the HA antibody $(\boldsymbol{E})$. Note the huge signal of GSK3 $\beta$ phosphorylation when the kinase was added to the reaction and another nearly twofold increase when 8-Br-cGMP was also included.

\section{A dominant active GSK3 $\beta$ phosphomutant inhibits cGMP- induced branching in DRG neurons}

To further test the role of GSK3 phosphorylation in cGMPinduced branching, we generated an expression construct for a GSK3 $\beta$ mutant (S9A), which had the phosphorylation site mutated from serine to alanine. Because the kinase can no longer be inactivated by phosphorylation (Eldar-Finkelman et al., 1996), we reasoned that this mutant could act as a dominant active kinase to prevent cGMP signaling from promoting branching. Indeed, DRG neurons expressing this mutant gen- 

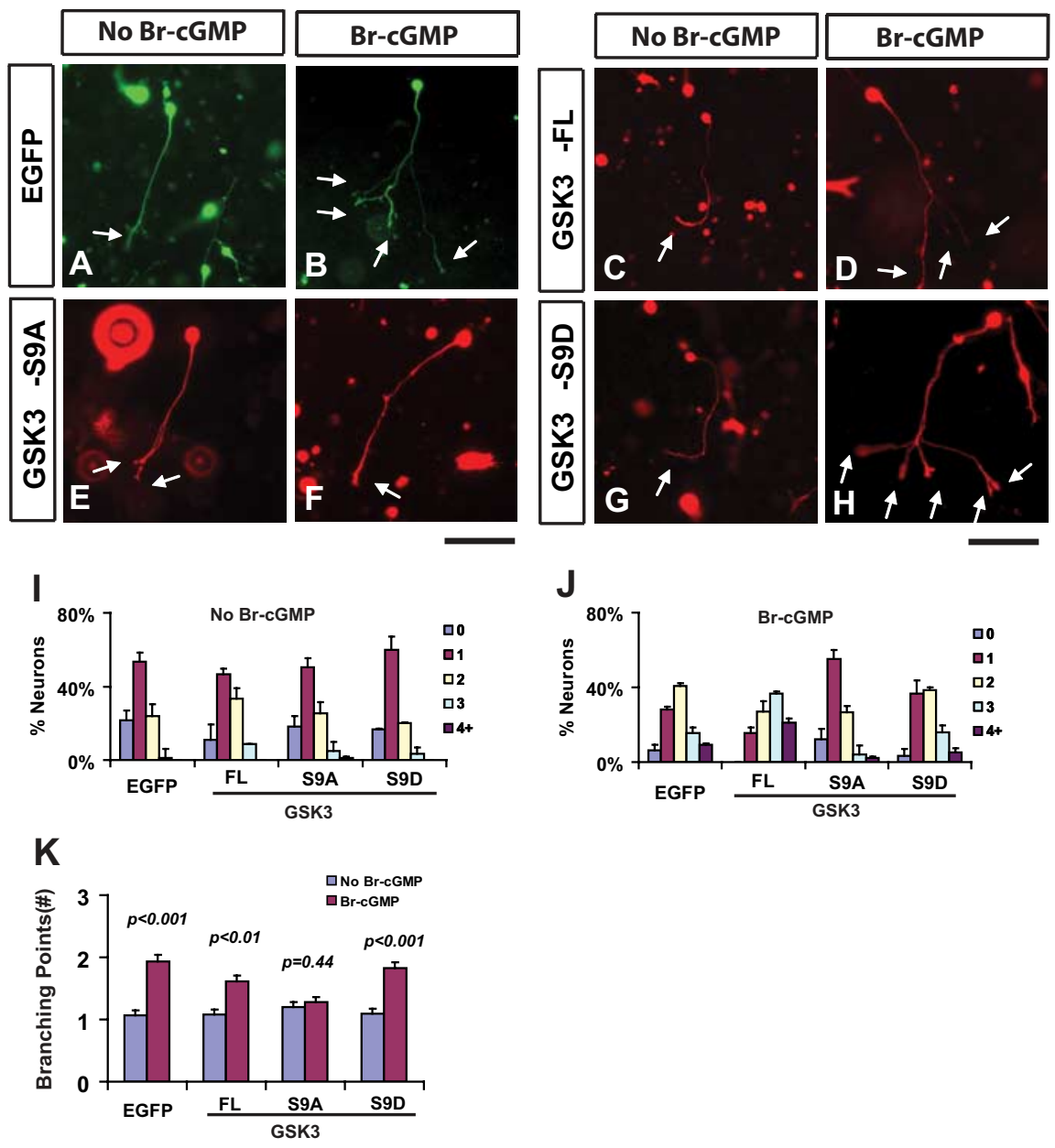

Figure 6. A dominant active GSK3 $\beta$ mutant blocks branch formation stimulated by 8-Br-cGMP in DRG neurons. $\boldsymbol{A}-\boldsymbol{H}$, Dissociated E14 DRG neurons were electroporated with plasmids expressing $\operatorname{EGFP}(\boldsymbol{A}, \boldsymbol{B}), \mathrm{GSK} 3 \beta$ full length (FL, C-D), the S9A mutant $(\boldsymbol{E}, \boldsymbol{F})$, or the S9D mutant $(\boldsymbol{G}, \boldsymbol{H})$, cultured in collagen gels, and treated without $(\boldsymbol{A}, \boldsymbol{C}, \boldsymbol{E}, \boldsymbol{G})$ or with $(\boldsymbol{B}, \boldsymbol{D}, \boldsymbol{F}, \boldsymbol{H}) 50 \mu \mathrm{m} 8-\mathrm{Br}-\mathrm{CGMP}$ for $1 \mathrm{~d}$. Cells are visualized with the EGFP fluorescence $(\boldsymbol{A}, \boldsymbol{B})$ or an antibody against the HA tag attached to GSK3 $\beta(\boldsymbol{C}-\boldsymbol{H})$. Expression of the S9A mutant blocked cGMP-induced branches ( $\boldsymbol{F}$, arrows), while expression of the wild type or the S9D mutant had no effect $(\boldsymbol{H})$. Note, many non-neuronal cells were also stained and shown in the background, and arrows point to the end of axonal branches. Scale bar, $100 \mu \mathrm{m}$. $\boldsymbol{I}-\boldsymbol{K}$, Comparison of the distribution of neurons with different branch numbers $(\boldsymbol{I}, \boldsymbol{J})$ and the number of branching points $(\boldsymbol{K})$ between cells expressing different proteins described above. Statistical differences are shown by the $p$ values.

erated much simpler morphology even in the presence of 8-Br-cGMP (Fig. 6E, F). At the basal level, the cell distribution as well as the number of branching points in these neurons was very similar to that of control cells expressing EGFP (Fig. $6 A, E)$. However, when these cells were treated with 8 -BrcGMP (Fig. $6 F$ ), the branched morphology normally exhibited in the control cells was completely abolished (Fig. 6B,F), with the average number of branching points dropped to that of unstimulated neurons (Fig. $6 K$ ). Not surprisingly, overexpression of the wild-type full-length GSK $3 \beta$ also reduced the response to cGMP activation, although to a lesser extent (Fig. $6 C, D)$. Finally, a phosphorylated mutant (S9D), which is inactive toward its downstream substrate, had no effect on the response of DRG neurons to 8-Br-cGMP (Fig. 6G-H, $I-K$ ).

To understand if GSK3 is the only downstream target shared by both cGMP and NGF signaling, we also examined other intermediate signaling molecules of the NGF pathways (Markus et al., 2002; Kim et al., 2006). First, inhibition of PI3-K by wortmannin and LY294002 reduced basal level branching to different extents but did not block new branch formation stimulated by 8 -Br-
cGMP (supplemental Fig. 7 $A, B$, available at www.jneurosci.org as supplemental material). Second, blocking ERK activity by U126 had no effect on CGMP-stimulated branching either. As a comparison, the inhibitory effect of these antagonists on 8-Br-cGMP-stimulated branching was $<10 \%$, while the inhibition by KT5823 and the S9A mutant of GSK3 $\beta$ reached $74 \%$ and $91 \%$, respectively (Fig. $7 B$ ). Therefore, these results suggest that GSK3 specifically mediates the downstream branching signaling of cGMP via the control of its phosphorylation.

\section{Discussion}

The development of axonal branches is critical to establishing functional and plastic neuronal circuits. Diverse branched axons have been documented for more than a century, but how they are formed remains to be one of the central questions in understanding circuitry formation. Although many factors can modulate branching morphogenesis, the intrinsic signaling mechanisms are not well defined. In this study, we provide evidence to show that the CGMP pathway provides one of such mechanisms. We have mapped the pathway to the upstream activator that produces cGMP, identified PrkG1 as the key molecular player, and linked the pathway to GSK3, a downstream kinase associated with cytoskeleton regulation. We propose that this pathway can provide a general mechanism to establish complex branched neuronal circuits and regulate synaptic plasticity in the brain.

\section{cGMP signaling can positively regulate axon branching during circuitry development}

Cyclic nucleotides including cAMP and cGMP have been known for their roles in regulating axon guidance in vitro (Song and Poo, 1999), yet no direct roles in regulating axon branching have been documented for either cyclic nucleotide. Here, we provide pharmacological, molecular, and genetic evidence to establish the involvement of the cGMP pathway in regulating axon branching, an important step in establishing neuronal circuits. Our results from cultured DRG neurons treated with pharmacological reagents as well as overexpressing PrkG1 mutants (Figs. 1,2) provide compelling evidence to demonstrate a direct role of this pathway in axon branching. In addition, our study of PrkG1 deficient mouse provides both in vitro and in vivo (Figs. 2,3) support for the requirement of the kinase in the formation of sensory circuitry in the spinal cord. These conclusions not only are consistent with the hypothesis that higher levels of cyclic nucleotides lead to positive regulation of axonal development (Song and Poo, 1999), but also further extend it to axon branching, a process that is intimately associated with but mechanistically different from axon guidance and growth. This notion is further supported by the loss of bifurcated branches in PrkG1 mutants (Fig. 3). Therefore, together with the study by Schmidt et al. 
(2007), our study has revealed a novel role of the cGMP pathway in regulating axon branching and demonstrated that such regulation is mediated by PrkG1.

How is the cGMP level controlled to fulfill this novel function in circuitry development? One route is mediated by membrane-bound guanylyl cyclases (mGCs) (Wedel and Garbers, 2001), as evidenced from the study of the receptor type mGC Npr2, which, like PrkG1, is required for bifurcation of DRG axons in mice (Schmidt et al., 2007). Such route of cGMP production is consistent with the genetic study of an mGC and its involvement in motor neurons pathfinding in flies (Ayoob et al., 2004). Alternatively, sGC (Friebe and Koesling, 2003) may provide a different route to produce cGMP, which is supported by our observation that sGC activation is sufficient to reproduce the same cGMP-induced branching phenotype in culture (Fig. 1). It is also consistent with the genetic study of the requirement of an sGC for optic nerve targeting in flies (Gibbs et al., 2001) and pharmacological study of sGC and its physiological activator nitric oxide in dendritic branching of motor neurons in mammals (Xiong et al., 2007).

Thus, the spatial and temporal regulation of cGMP production can provide a versatile mechanism to pattern different axonal branches during development, although further studies are needed. We speculate that this pathway can also regulate synaptic plasticity, as rapid production of cGMP locally provides an efficient mean to induce structural changes necessary for synaptic remodeling. In fact, many enzymes involved in cGMP production and stability are expressed in the synapses and implicated in synaptic transmission (Mungrue and Bredt, 2004). This proposition is also consistent with the reduced long-term potentiation in hippocampus and the loss of long-term depression in cerebellar Purkinje cells found in PrkG1 mutant mice (Feil et al., 2003; Kleppisch et al., 2003), but detailed analyses are needed to link the morphological changes to synaptic modulation in the future.

\section{Axon bifurcation: a looking glass into the cellular mechanism of axon branching}

Although the branched morphology of cultured DRG neurons is quite different from bifurcation regulated by PrkG1 in vivo, our studies of mice lacking either cGMP or Slit signaling suggest that they may well share a common cellular mechanism. Despite the loss of one daughter branch, the proper turning of the DRG axon in the PrkG1 mutant (Fig. 3) (Schmidt et al., 2007) suggests that bifurcation involves branching and guidance, two separate events regulated by different signals. This idea is supported by the defect found in the Slit mutants, where neither branch is lost but one branch misprojects into the spinal cord (Ma and Tessier-Lavigne, 2007). These phenotypes are consistent with the model in which the two branches are not created equally but have different molecular and biochemical properties. For example, one axon, likely the incoming primary axon, can respond to Slit to stop at the DREZ and turn into the longitudinal track; the other axon may emerge from the turning point as a collateral branch in a process that is regulated by cGMP signaling locally.

Such a model in which a bifurcated axon arises from a collat- eral branch indicates that bifurcation may be a special case of a common branching process shaped by multiple local environmental cues. This explains the difference in morphologies between bifurcated DRG axons in mice and cGMP-stimulated branches in culture, as the lack of other physiological cues to control proper guidance permits cGMP-activated axons to form multiple branches in culture (Fig. 1). This model is also consistent with the recent in vivo observation of cortical axons, which do not split growth cones to make collateral branches (PorteraCailliau et al., 2005). However, further studies will be needed to test this model and understand how branching and guidance are regulated coordinately by local cues to generate bifurcated axon as well as other branching patterns.

\section{Activation of cGMP signaling modulates a common branching pathway}

Although several substrates have been identified in non-neuronal cells (Hofmann et al., 2000), little is known about the factors that mediate the activity of cGMP signaling in axonal development. Only L-type calcium channel has recently been implicated in cAMP/cGMP-regulated growth cone turning (Nishiyama et al., 2003). Our study now provides both biochemical and molecular evidence to directly link cGMP signaling to GSK3, a molecule known to phosphorylate cytoskeletal proteins (Zhou et al., 2004; Yoshimura et al., 2005). Consistent with the observation that inhibiting GSK3 activity promotes branch formation (Kim et al., 2006), we find that PrkG1 activation leads to the phosphorylation of GSK3 in DRG neurons while overexpression of a nonphosphorylated form of GSK3 $\beta$ blocks the branching activity. More importantly, we find a direct interaction between PrkG1 and GSK $3 \beta$ that is supported by their biochemical properties as enzyme and substrate and consistent with GSK3 being phosphorylated by the PrkG2 in osteoblasts and chondrocytes (Zhao et al., 2005; Kawasaki et al., 2008). Thus, our study identifies GSK3 as a new substrate for PrkG1 in mediating the branching activity of cGMP signaling in axonal development.

This conclusion is consistent with a recent proposal that GSK3 is a convergent point for regulatory pathways to control axonal 
morphology (Kim et al., 2006). In this proposal, GSK3 inactivation in the growth cone mediates NGF-dependent axon growth, while partial inactivation along the axons leads to nonpolarized activation of primed substrates CRMP2 and APC along the axon and hence branch formation. Since the level of cGMP-dependent GSK phosphorylation is half of that from NGF treatment in DRG neurons, it is conceivable that this model explains the branching phenotype observed in culture. In addition, the bifurcation defect is consistent with the idea that local inhibition of GSK3 leads to branch formation by activating CRMP2 and APC, two proteins that control microtubule assembly (Kim et al., 2006). In fact, GSK3 regulates the association of CRMP2 with microtubules in establishing neuronal polarization (Yoshimura et al., 2005), and mediates APC localization and microtubule assembly in the growth cone that is regulated by Wnt signaling, another pathway that can promote branching in DRG neurons (Purro et al., 2008). Although the exact detail remains to be worked out, local modulation of microtubule assembly via the control of GSK activity could provide a key mechanism to link cell signaling to the cytoskeleton in branching morphogenesis.

The link between GSK3 and cGMP also reinforces the idea that cGMP signaling regulates axon branching but not growth. GSK3 is part of a pathway involved in NGF signaling in axonal development, and overexpression of its upstream kinase Akt promotes branching in DRG neurons (Markus et al., 2002). Although Akt was not found to be the target, our study connects cGMP signaling to GSK3 in the middle of a pathway involved in branching. Moreover, cGMP signaling does not target the separate Raf pathway that mediates NGF-dependent axon growth (Zhong et al., 2007). Thus, our study reveals that cGMP signaling is linked to a common pathway that controls axon branching during circuitry development.

\section{References}

Ayoob JC, Yu HH, Terman JR, Kolodkin AL (2004) The Drosophila receptor guanylyl cyclase Gyc76C is required for semaphorin-1a-plexin A-mediated axonal repulsion. J Neurosci 24:6639-6649.

Barnstable CJ, Wei JY, Han MH (2004) Modulation of synaptic function by cGMP and cGMP-gated cation channels. Neurochem Int 45:875-884.

Browning DD, Mc Shane M, Marty C, Ye RD (2001) Functional analysis of type lalpha cGMP-dependent protein kinase using green fluorescent fusion proteins. J Biol Chem 276:13039-13048.

Busch JL, Bessay EP, Francis SH, Corbin JD (2002) A conserved serine juxtaposed to the pseudosubstrate site of type I cGMP-dependent protein kinase contributes strongly to autoinhibition and lower cGMP affinity. J Biol Chem 277:34048-34054.

Cogen J, Cohen-Cory S (2000) Nitric oxide modulates retinal ganglion cell axon arbor remodeling in vivo. J Neurobiol 45:120-133.

Dent EW, Tang F, Kalil K (2003) Axon guidance by growth cones and branches: common cytoskeletal and signaling mechanisms. Neuroscientist 9:343-353.

Dundore RL, Clas DM, Wheeler LT, Habeeb PG, Bode DC, Buchholz RA, Silver PJ, Pagani ED (1993) Zaprinast increases cyclic GMP levels in plasma and in aortic tissue of rats. Eur J Pharmacol 249:293-297.

Eldar-Finkelman H, Argast GM, Foord O, Fischer EH, Krebs EG (1996) Expression and characterization of glycogen synthase kinase-3 mutants and their effect on glycogen synthase activity in intact cells. Proc Natl Acad Sci U S A 93:10228-10233.

Feil R, Hartmann J, Luo C, Wolfsgruber W, Schilling K, Feil S, Barski JJ, Meyer M, Konnerth A, De Zeeuw CI, Hofmann F (2003) Impairment of LTD and cerebellar learning by Purkinje cell-specific ablation of cGMPdependent protein kinase I. J Cell Biol 163:295-302.

Feil R, Hofmann F, Kleppisch T (2005) Function of cGMP-dependent protein kinases in the nervous system. Rev Neurosci 16:23-41.

Fiscus RR (2002) Involvement of cyclic GMP and protein kinase G in the regulation of apoptosis and survival in neural cells. Neurosignals 11:175-190.
Friebe A, Koesling D (2003) Regulation of nitric oxide-sensitive guanylyl cyclase. Circ Res 93:96-105.

Galle J, Zabel U, Hübner U, Hatzelmann A, Wagner B, Wanner C, Schmidt HH (1999) Effects of the soluble guanylyl cyclase activator, YC-1, on vascular tone, cyclic GMP levels and phosphodiesterase activity. $\mathrm{Br} \mathrm{J}$ Pharmacol 127:195-203.

Gibbs SM, Truman JW (1998) Nitric oxide and cyclic GMP regulate retinal patterning in the optic lobe of Drosophila. Neuron 20:83-93.

Gibbs SM, Becker A, Hardy RW, Truman JW (2001) Soluble guanylate cyclase is required during development for visual system function in Drosophila. J Neurosci 21:7705-7714.

Hidaka H, Kobayashi R (1992) Pharmacology of protein kinase inhibitors. Annu Rev Pharmacol Toxicol 32:377-397.

Hofmann F, Ammendola A, Schlossmann J (2000) Rising behind NO: cGMP-dependent protein kinases J Cell Sci 113:1671-1676.

Kawasaki Y, Kugimiya F, Chikuda H, Kamekura S, Ikeda T, Kawamura N, Saito T, Shinoda Y, Higashikawa A, Yano F, Ogasawara T, Ogata N, Hoshi K, Hofmann F, Woodgett JR, Nakamura K, Chung UI, Kawaguchi H (2008) Phosphorylation of GSK-3beta by cGMP-dependent protein kinase II promotes hypertrophic differentiation of murine chondrocytes. J Clin Invest 118:2506-2515.

Kim WY, Zhou FQ, Zhou J, Yokota Y, Wang YM, Yoshimura T, Kaibuchi K, Woodgett JR, Anton ES, Snider WD (2006) Essential roles for GSK-3s and GSK-3-primed substrates in neurotrophin-induced and hippocampal axon growth. Neuron 52:981-996.

Kleppisch T, Wolfsgruber W, Feil S, Allmann R, Wotjak CT, Goebbels S, Nave KA, Hofmann F, Feil R (2003) Hippocampal cGMP-dependent protein kinase I supports an age- and protein synthesis-dependent component of long-term potentiation but is not essential for spatial reference and contextual memory. J Neurosci 23:6005-6012.

Lein ES, Hawrylycz MJ, Ao N, Ayres M, Bensinger A, Bernard A, Boe AF, Boguski MS, Brockway KS, Byrnes EJ, Chen L, Chen TM, Chin MC, Chong J, Crook BE, Czaplinska A, Dang CN, Datta S, Dee NR, Desaki AL, et al (2007) Genome-wide atlas of gene expression in the adult mouse brain. Nature 445:168-176.

Lentz SI, Knudson CM, Korsmeyer SJ, Snider WD (1999) Neurotrophins support the development of diverse sensory axon morphologies. J Neurosci 19:1038-1048.

Ma L, Tessier-Lavigne M (2007) Dual branch-promoting and branchrepelling actions of Slit/Robo signaling on peripheral and central branches of developing sensory axons. J Neurosci 27:6843-6851.

Markus A, Zhong J, Snider WD (2002) Raf and akt mediate distinct aspects of sensory axon growth. Neuron 35:65-76.

Mungrue IN, Bredt DS (2004) nNOS at a glance: implications for brain and brawn. J Cell Sci 117:2627-2629.

Nishiyama M, Hoshino A, Tsai L, Henley JR, Goshima Y, Tessier-Lavigne M, Poo MM, Hong K (2003) Cyclic AMP/GMP-dependent modulation of $\mathrm{Ca} 2+$ channels sets the polarity of nerve growth-cone turning. Nature 423:990-995.

O'Leary DD, Terashima T (1988) Cortical axons branch to multiple subcortical targets by interstitial axon budding: implications for target recognition and "waiting periods". Neuron 1:901-910.

Ozaki S, Snider WD (1997) Initial trajectories of sensory axons toward laminar targets in the developing mouse spinal cord. J Comp Neurol 380:215-229.

Polleux F, Morrow T, Ghosh A (2000) Semaphorin 3A is a chemoattractant for cortical apical dendrites. Nature 404:567-573.

Portera-Cailliau C, Weimer RM, De Paola V, Caroni P, Svoboda K (2005) Diverse modes of axon elaboration in the developing neocortex. PLoS Biol 3:e272.

Purro SA, Ciani L, Hoyos-Flight M, Stamatakou E, Siomou E, Salinas PC (2008) Wnt regulates axon behavior through changes in microtubule growth directionality: a new role for adenomatous polyposis coli. J Neurosci 28:8644-8654.

Qian Y, Chao DS, Santillano DR, Cornwell TL, Nairn AC, Greengard P, Lincoln TM, Bredt DS (1996) cGMP-dependent protein kinase in dorsal root ganglion: relationship with nitric oxide synthase and nociceptive neurons. J Neurosci 16:3130-3138.

Schmidt H, Werner M, Heppenstall PA, Henning M, Moré MI, Kühbandner S, Lewin GR, Hofmann F, Feil R, Rathjen FG (2002) cGMP-mediated signaling via cGKIalpha is required for the guidance and connectivity of sensory axons. J Cell Biol 159:489-498. 
Schmidt H, Stonkute A, Jüttner R, Schäffer S, Buttgereit J, Feil R, Hofmann F, Rathjen FG (2007) The receptor guanylyl cyclase Npr2 is essential for sensory axon bifurcation within the spinal cord. J Cell Biol 179:331-340.

Schwarzschild MA, Zigmond RE (1991) Effects of peptides of the secretinglucagon family and cyclic nucleotides on tyrosine hydroxylase activity in sympathetic nerve endings. J Neurochem 56:400-406.

Seidel C, Bicker G (2000) Nitric oxide and cGMP influence axonogenesis of antennal pioneer neurons. Development 127:4541-4549.

Song H, Poo M (2001) The cell biology of neuronal navigation. Nat Cell Biol 3:E81-E88.

Song HJ, Poo MM (1999) Signal transduction underlying growth cone guidance by diffusible factors. Curr Opin Neurobiol 9:355-363.

Thippeswamy T, Morris R (1997) Cyclic guanosine 3', $5^{\prime}$-monophosphatemediated neuroprotection by nitric oxide in dissociated cultures of rat dorsal root ganglion neurones. Brain Res 774:116-122.

Wang KH, Brose K, Arnott D, Kidd T, Goodman CS, Henzel W, TessierLavigne M (1999) Biochemical purification of a mammalian slit protein as a positive regulator of sensory axon elongation and branching. Cell 96:771-784.

Wedel B, Garbers D (2001) The guanylyl cyclase family at Y2K. Annu Rev Physiol 63:215-233.

Wegener JW, Nawrath H, Wolfsgruber W, Kühbandner S, Werner C, Hof- mann F, Feil R (2002) cGMP-dependent protein kinase I mediates the negative inotropic effect of cGMP in the murine myocardium. Circ Res 90:18-20.

Xiong G, Mojsilovic-Petrovic J, Pérez CA, Kalb RG (2007) Embryonic motor neuron dendrite growth is stunted by inhibition of nitric oxidedependent activation of soluble guanylyl cyclase and protein kinase G. Eur J Neurosci 25:1987-1997.

Yoshimura T, Kawano Y, Arimura N, Kawabata S, Kikuchi A, Kaibuchi K (2005) GSK-3beta regulates phosphorylation of CRMP-2 and neuronal polarity. Cell 120:137-149.

Zhao X, Zhuang S, Chen Y, Boss GR, Pilz RB (2005) Cyclic GMP-dependent protein kinase regulates CCAAT enhancer-binding protein beta functions through inhibition of glycogen synthase kinase-3. J Biol Chem 280:32683-32692.

Zhong J, Li X, McNamee C, Chen AP, Baccarini M, Snider WD (2007) Raf kinase signaling functions in sensory neuron differentiation and axon growth in vivo. Nat Neurosci 10:598-607.

Zhou FQ, Zhou J, Dedhar S, Wu YH, Snider WD (2004) NGF-induced axon growth is mediated by localized inactivation of GSK-3beta and functions of the microtubule plus end binding protein APC. Neuron 42:897-912. 